\title{
Endotoxin induces proliferation of NSCLC in vitro and in vivo: role of COX-2 and EGFR activation
}

\author{
Katja Hattar • Rajkumar Savai - Florentine S. B. Subtil · Jochen Wilhelm • Anja Schmall • \\ Dagmar S. Lang • Torsten Goldmann • Bastian Eul • Gabriele Dahlem • Ludger Fink • \\ Ralph-Theo Schermuly • Gamal-Andre Banat • Ulf Sibelius • Friedrich Grimminger • \\ Ekkehard Vollmer · Werner Seeger · Ulrich Grandel
}

Received: 31 January 2012/ Accepted: 11 August 2012/Published online: 26 August 2012

(C) The Author(s) 2012. This article is published with open access at Springerlink.com

\begin{abstract}
Lung cancer is frequently complicated by pulmonary infections which may impair prognosis of this disease. Therefore, we investigated the effect of bacterial lipopolysaccharides (LPS) on tumor proliferation in vitro in the non-small cell lung cancer (NSCLC) cell line A549, ex vivo in a tissue culture model using human NSCLC specimens and in vivo in the A549 adenocarcinoma mouse model. LPS induced a time- and dose-dependent increase
\end{abstract}

K. Hattar · B. Eul · G. Dahlem · G.-A. Banat · U. Sibelius ·

F. Grimminger · U. Grandel ( $\square)$

Department of Internal Medicine IV/V, University

of Giessen and Marburg Lung Center (UGMLC),

Klinikstrasse 33, Giessen, Germany

e-mail: ulrich.grandel@innere.med.uni-giessen.de

R. Savai - A. Schmall - R.-T. Schermuly · W. Seeger

Max-Planck Institute for Heart and Lung Research,

Bad Nauheim, Germany

F. S. B. Subtil

Department of Radiotherapy and Radiooncology,

Philipps-University, Marburg, Germany

J. Wilhelm

Department of Internal Medicine II, Biostatistics Group,

University of Giessen and Marburg Lung Center (UGMLC),

Giessen, Germany

D. S. Lang · T. Goldmann · E. Vollmer

Clinical and Experimental Pathology, Research Center Borstel,

Borstel, Germany

L. Fink

Department of Pathology, University of Giessen and Marburg

Lung Center (UGMLC), Giessen, Germany

R.-T. Schermuly · W. Seeger

Department of Internal Medicine II, University of Giessen

and Marburg Lung Center (UGMLC), Giessen, Germany in proliferation of A549 cells as quantified by MTS activity and cell counting. In parallel, an increased expression of the proliferation marker $\mathrm{Ki}-67$ and cyclooxygenase (COX)2 was detected both in A549 cells and in ex vivo human NSCLC tissue. Large amounts of COX-2-derived prostaglandin $(\mathrm{PG}) \mathrm{E}_{2}$ were secreted from LPS-stimulated A549 cells. Pharmacological interventions revealed that the proliferative effect of LPS was dependent on CD14 and Toll-like receptor (TLR)4. Moreover, blocking of the epidermal growth factor receptor (EGFR) also decreased LPSinduced proliferation of A549 cells. Inhibition of COX-2 activity in A549 cells severely attenuated both $\mathrm{PGE}_{2}$ release and proliferation in response to LPS. Synthesis of $\mathrm{PGE}_{2}$ was also reduced by inhibiting CD14, TLR4 and EGFR in A549 cells. The proliferative effect of LPS on A549 cells could be reproduced in the A549 adenocarcinoma mouse model with enhancement of tumor growth and Ki-67 expression in implanted tumors. In summary, LPS induces proliferation of NSCLC cells in vitro, ex vivo in human NSCLC specimen and in vivo in a mouse model of NSCLC. Pulmonary infection may thus directly induce tumor progression in NSCLC.

Keywords Lung cancer - Infection - Endotoxin - Tumor proliferation · Inflammation

\section{Introduction}

Infections are considered to promote growth of human cancer. Roughly estimated, about $15 \%$ of all malignancies worldwide can be attributed to infectious agents [1]. Although the contribution of different viruses to the development of malignancies has been well recognized, some chronic bacterial infections are also associated with 
tumor formation [2]. In this context, the most prominent example is Helicobacter pylori, which is an important risk factor for gastric cancer [3, 4].

In lung cancer, one of the leading causes of cancerrelated death in the western hemisphere, the association between bacterial infections and cancer development is less obvious. Lung cancer patients frequently suffer from pulmonary infections, and the most common pathogens found in patients with lung cancer are gram-negative bacteria such as Haemophilus influenzae and E. coli [5, 6]. Although pulmonary infections have been related to a reduction in the median survival of patients with lung cancer [7], it is not clear whether bacterial infections worsen prognosis of lung cancer by actually accelerating tumor growth and metastasis formation. However, it is well established that persistent inflammation can activate cancer growth [8, 9], and in NSCLC, a prominent role for COX-2derived lipid mediators has been postulated in this context $[10,11]$. In vivo, COX-2 protein and mRNA levels are elevated and are associated with a poor prognosis in lung adenocarcinoma [12, 13]. In vitro, overexpression of COX2 directly increases survival of lung adenocarcinoma cell lines [14]. $\mathrm{PGE}_{2}$ is the major COX-2-derived metabolite up-regulated in human lung cancer tissue and cell lines $[15,16]$. Direct inhibition of apoptosis and an EGFRassociated signaling have been characterized as molecular mechanisms of $\mathrm{PGE}_{2}$-induced tumor growth [17].

Regarding NSCLC, COX-2 expression and $\mathrm{PGE}_{2}$ production in epithelial cancer cell lines have been shown to be induced by benzo[a]pyrene, a potent carcinogen contained in cigarette smoke [18]. In bronchial epithelial cells, however, COX-2 is also induced by endogenous and exogenous proinflammatory stimuli such as the bacterial membrane glycolipid LPS [19, 20], suggesting a relevant role for infectious agents in this context. In general, cellular activation by LPS is initiated via the CD14 surface receptor, a GPI-anchored glycoprotein [21] and TLRs, such as TLR4 [22, 23]. However, some LPS types, mainly from non-enterobacteria are recognized by TLR2, presumably due to differences in the lipid A component [24].

In gastric cancer, the expression of different TLRs enables gastric carcinoma cells to interact with Helicobacter pylori [25]. This interaction may be followed by the production of tumor-promoting factors such as IL-8. Most importantly, an up-regulation of TLR4 expression was recently demonstrated in human adenocarcinoma of the lung in vivo, and TLR4 expression levels correlated with malignancy [26]. Thus, specific interactions between bacterial pathogens such as LPS and tumor cells may actually occur in NSCLC. However, the consequences of such interactions for tumor cell biology are less clear.

In the current study, we focused on the effects of bacterial endotoxin in vitro on proliferation of A549 cells, a cell line derived from human lung adenocarcinoma, in an ex vivo short-term cultivation model designated short-term stimulation of tissues (STST) using human specimens obtained from patients with NSCLC and in vivo in the subcutaneous A549 adenocarcinoma mouse model. In essence, we found that LPS strongly induces proliferation in these experimental models, which was mediated by COX-2 activation. Furthermore, interference with CD14, TLR4 and EGFR attenuated the proliferative response to LPS. Thus, our data suggest that LPS exposure as a consequence of pulmonary infections could potentially accelerate tumor progression in lung cancer.

\section{Materials and methods}

\section{Cell culture}

The A549 human lung adenocarcinoma cell line was obtained from the American Type Culture Collection (ATCC, Rockville, MD, USA) and cultured at $37{ }^{\circ} \mathrm{C}$ in a humidified atmosphere (95\% air, $5 \% \mathrm{CO} 2$ ). All cell culture media and supplements were purchased from Gibco (Eggenstein, Germany) unless otherwise indicated. The cells were kept in Dulbecco's modified Eagle's medium (DMEM/F12), supplemented with $10 \%$ FCS, $2 \mathrm{mM}$ L-glutamine, $10^{5} \mathrm{U} / \mathrm{l}$ penicillin and $100 \mathrm{mg} / \mathrm{l}$ streptomycin. Cells were grown to confluence and subcultured every 2-3 days and split at a ratio of 1:10.

Ex vivo cultivation and stimulation of human lung cancer tissues

Three specimens of human NSCLC of adenocarcinoma type were cultured using a novel short-term tissue cultivation model ex vivo as previously reported [27]. Briefly, vital tissue samples were cultured in $2 \mathrm{ml}$ RPMI 1640 supplemented with $10 \% \mathrm{FCS}$ at $37{ }^{\circ} \mathrm{C}$ and $5 \% \mathrm{CO} 2$ for $16 \mathrm{~h}$ in the presence or absence of $10 \mu \mathrm{g} / \mathrm{ml}$ of a highly purified LPS from E. coli F515 (kindly provided by Prof. Otto Holst, Immunochemistry Group, Research Center Borstel, Germany) [28]. After termination of the cultivation period [27], the specimens were fixed by the HOPEtechnique and embedded in paraffin as described elsewhere [29]. Accordingly, the tissue samples were always deparaffinized for subsequent analyses (immunohistochemistry and molecular analysis).

A549 adenocarcinoma mouse model

Tumor growth was assessed by subcutaneous injection of A549 cells $\left(2.5 \times 10^{6}\right.$ cells $/ 200 \mu \mathrm{l}$ in PBS $)$ into 8-weekold female $\mathrm{BALBc} / \mathrm{c}$ nu/nu mice. These mice were 
purchased from Charles River (Sulzfeld, Germany) and kept under specific pathogen-free conditions. Immediately before subcutaneous injection, A549 cells were treated with highly purified E.coli LPS F515 $(n=6)$ or sham incubation with PBS (control, $n=8$ ) was performed. Animals were handled in accordance with the European Community recommendations for experimentation. The size of the tumor was measured at days 4, 8 and 12 after implantation by Mitutoyo digital calipers (Mitutoyo Ltd., UK), as previously described [30]. The tumor volume (TV) was calculated by the formula TV $\left(\mathrm{mm}^{3}\right)=\left(L \times W^{2}\right) / 2$, where $L$ is the longest dimension of the tumor (in $\mathrm{mm}$ ) and $W$ is the shortest dimension of the tumor (in $\mathrm{mm}$ ). Each tumor measurement was taken in triplicate by two different investigators (K.H. and R.S.)

\section{MTS assay}

The MTS assay (CellTiter 96@ Aqueous One Solution Cell Proliferation Assay, Promega, Mannheim, Germany) quantifies the metabolic activity of cells. This assay is based upon the cleavage of the yellow 3-(4, 5-dimethylthiazol-2-yl)-5-(3-carboxymethoxyphenyl)-2-(4-sulfophenyl)-2H-tetrazolium, inner salt (MTS) to purple formazan by metabolic active cells. The production of the colored formazan product is directly proportional to the number of viable cells in culture [31]. Based on these data, the MTS
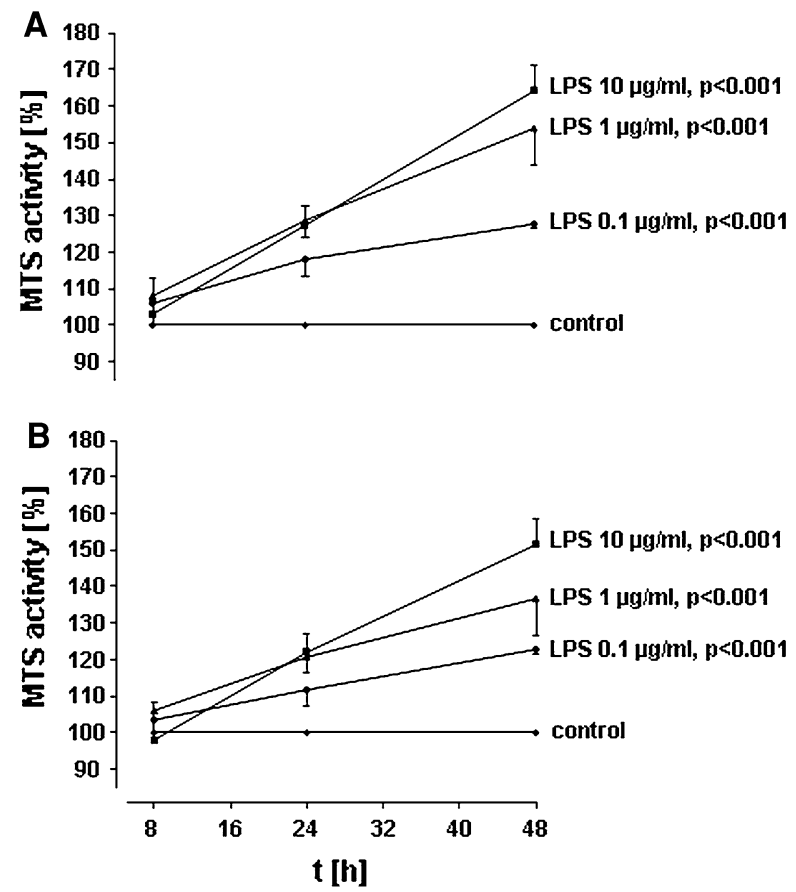

Fig. 1 Time-and dose-dependent induction of A59 proliferation by LPS. A549 cells were incubated with various concentrations of LPS from $E$. coli $0111: \mathrm{B} 4(\mathbf{a} / \mathbf{c})$ or highly purified LPS from E. coli F515 (b/d) or sham incubation was performed (control). A549 proliferation assay is widely used for the assessment of cellular proliferation.

In brief, A549 cells were seeded on 96-well plates (2,500 cells/well) and maintained in culture for $24 \mathrm{~h}$ before LPS stimulation. Then, medium was exchanged, and cells were kept in RPMI containing $1 \%$ FCS at a total volume of $200 \mu 1 /$ well. A549 cells were stimulated with different concentrations of LPS (E. coli LPS 0111:B4, Sigma, Deisenhofen, Germany or highly purified E.coli LPS F515) for various time periods or sham incubation (control) was performed. For Fig. 1a with LPS from E. coli 0111:B4, at least five independent experiments were performed, and for Fig. 1b with LPS from E. coli F515, at least four independent experiments were performed. In an additional series of experiments in Fig. 2, function-blocking antibodies targeting TLR2 (clone TL2.1, e-Bioscience, San Diego, CA, USA), TLR4 (clone HTA 125, e-Bioscience, San Diego, CA, USA), CD14 (MY-4, Coulter Immunotech, Hamburg, Germany), EGFR (Cetuximab, Merck Serono, Germany) or COX inhibitors (indomethacin, Sigma, Deisenhofen, Germany and NS-398, Calbiochem, La Jolla, CA, USA) were applied simultaneously to LPS. For these inhibitor studies, at least six independent experiments were performed (at least 3 both for LPS 0111:B4 and for LPS F515, respectively).

At the end of the incubation, $20 \mu \mathrm{l}$ of MTS solution were added to each well and plates were again incubated
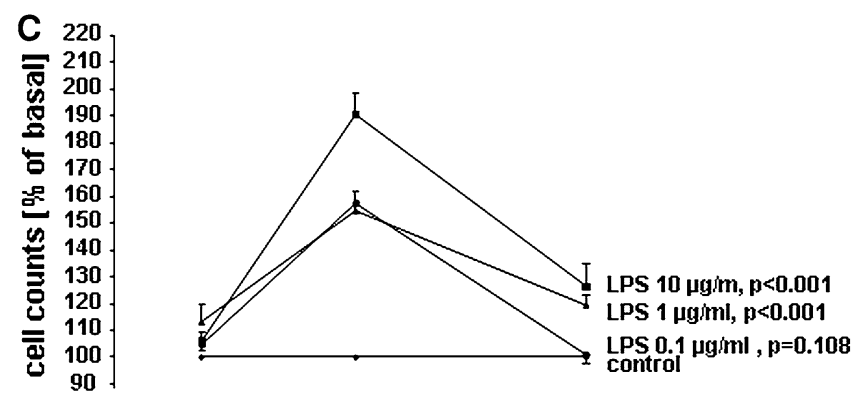

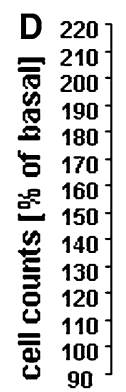

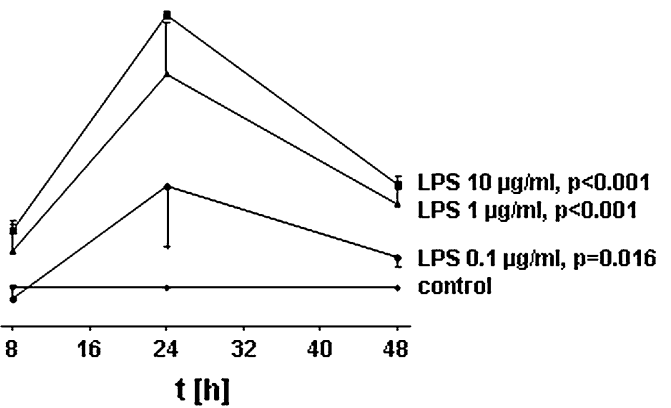

was assessed by measuring MTS activity $(\mathbf{a} / \mathbf{b})$ and automatic cell counting (c/d). All data are expressed as percentage of unstimulated cells (control). Mean \pm SEM of at least four independent experiments are given 


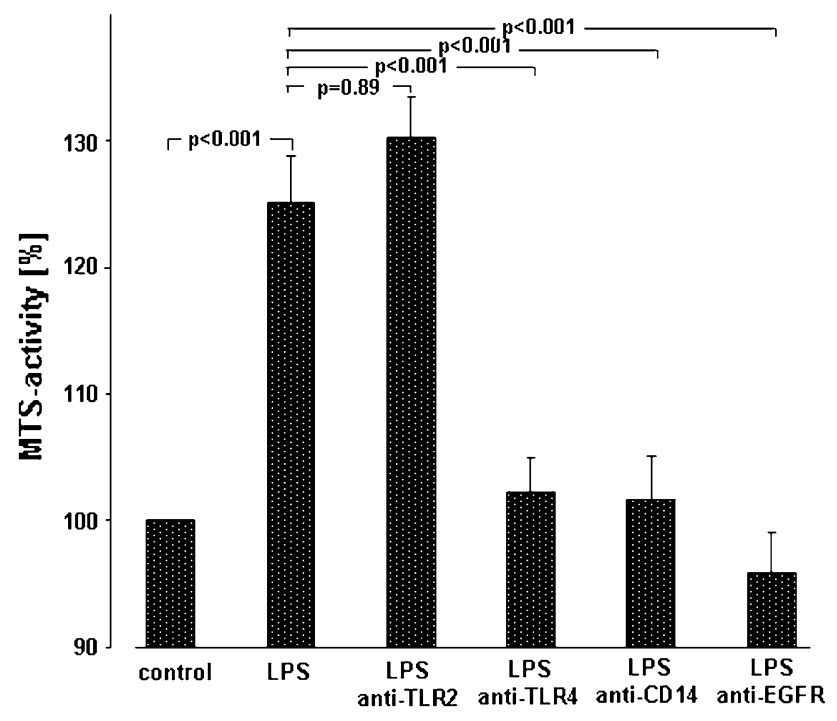

Fig. 2 Mechanisms of LPS-induced A549 proliferation. A549 cells were either sham-incubated (control) or exposed to $10 \mu \mathrm{g} / \mathrm{ml}$ of LPS ( $n=3$ for LPS 0111:B4 and $n=3$ for LPS F515, total $n=6$ ) in the absence or presence of neutralizing antibodies targeting TLR2, TLR4, CD14 or EGFR. After $24 \mathrm{~h}$ of incubation proliferation was quantified by determining MTS activity. All data are expressed as percentage of unstimulated cells (control). Mean \pm SEM of six independent experiments are given

for $2.5 \mathrm{~h}$ at $37{ }^{\circ} \mathrm{C}$. Absorbance was read at $490 \mathrm{~nm}$, background readings were subtracted from the sample wells, and data were expressed as percentage of controls (sham-incubated cells). All samples were run in triplicate, and all measurements were taken twice after $2.5 \mathrm{~h}$ of incubation with the MTS reagent. All data were expressed as percentage increase in MTS activity compared to unstimulated cells (controls), which were set to $100 \%$.

Assessment of cellular proliferation by cell counting

For cell counting, A549 cells were seeded on 24-well plates $(50,000$ cells/well) and maintained in culture for $24 \mathrm{~h}$ before LPS stimulation. Then, medium was exchanged, and cells were kept in RPMI containing $1 \%$ FCS at a total volume of $500 \mu \mathrm{l} /$ well. A549 cells were stimulated with different concentrations of LPS (E. coli LPS 0111:B4 or E. coli LPS F515) or sham-incubated (control). For each LPS type in Fig. 1c, d, at least four independent experiments were performed. At the end of the incubation period, the medium was removed, and cells were washed, detached by treatment with $0.5 \%$ trypsin-EDTA, resuspended in a stop-solution containing $20 \%$ FCS in PBS and finally counted by the cell counter-analyzer system Casy Model TT (Innovatis AG, Reutlingen, Germany). Data were expressed as percentage of controls (sham-incubated cells), which were set to $100 \%$. All samples were performed in triplicate, and all measurements were taken three times in
$200 \mu \mathrm{l}$ cell casyton suspension each. The orifice tube had an aperture size of $150 \mu \mathrm{m}$.

Measurement of $\mathrm{PGE}_{2}$ and thromboxane $\mathrm{A}_{2}$

$\mathrm{PGE}_{2}$ and thromboxane $(\mathrm{Tx}) \mathrm{B}_{2}$, the stable hydrolysis product of $\mathrm{TxA}_{2}$, were quantified in a commercial ELISA system (R\&D Systems, Wiesbaden, Germany) according to the manufacturer's instructions. For these experiments, A549 cells $(50,000$ cells/well) were seeded on 24 -well plates and grown to confluence. Confluent monolayers were washed twice and kept in RPMI containing $1 \%$ FCS at a total volume of $500 \mu \mathrm{l} /$ well. Then, incubation with different concentrations of LPS (from E. coli 0111:B4 or E. coli $\mathrm{F} 515)$ in the absence or presence of the respective antibodies or COX inhibitors for various time periods, or sham incubation (control) was performed. All samples were performed as duplicate. For the time-response curve in Fig. 3c, as well as for the inhibitor studies in Fig. 3a, at least six independent experiments were performed (at least 3 both for LPS 0111:B4 and for LPS F515, respectively). At the end of the incubation period, medium was exchanged, and cells were washed twice and kept in RPMI containing $1 \%$ FCS and further incubated for $8 \mathrm{~h}$ with $5 \mu \mathrm{M}$ arachidonic acid (AA, Sigma, Deisenhofen, Germany). Then, cell supernatants were harvested, cell debris was removed by centrifugation at $13.000 \times g$, and samples were stored at $-20{ }^{\circ} \mathrm{C}$ until further processing. The measurement of $\mathrm{PGE}_{2}$ and $\mathrm{TxB}_{2}$ release was taken by ELISA technique, according to the manufacturer's protocols and is expressed in $\mathrm{pg} / \mathrm{ml}$. All samples were performed as duplicate, and each sample was measured twice.

\section{RNA isolation and real-time RT-PCR}

For quantification of COX-2 in fig. $3 b, \mathrm{Ki}-67$ and PCNA mRNA, experiments with A549 cells (50,000 cells/well) or short-term stimulation of lung cancer tissues were performed as described above for $16 \mathrm{~h}$. Total RNA was extracted from cells and lung cancer tissues with TRIzol reagent (Invitrogen, Karlsruhe, Germany) or RNeasy minikit (Qiagen, Hilden, Germany), following the manufacturer's protocols. The yield of extracted RNA was determined by Nano Drop (PeqLab, Erlangen, Germany). After digesting residual DNA with DNase (Invitrogen, Karlsruhe, Germany), cDNA was synthesized by RT (Promega, Mannheim, Germany or Applied Biosystems, Darmstadt, Germany). Real-time PCR was performed using $1 \mu \mathrm{g}$ of cDNA, SYBR Green PCR Master Mix (Invitrogen, Karlsruhe, Germany) and $0.05 \mathrm{M}$ forward/ reverse primers; specific primers used for sequence detection were as follows: 

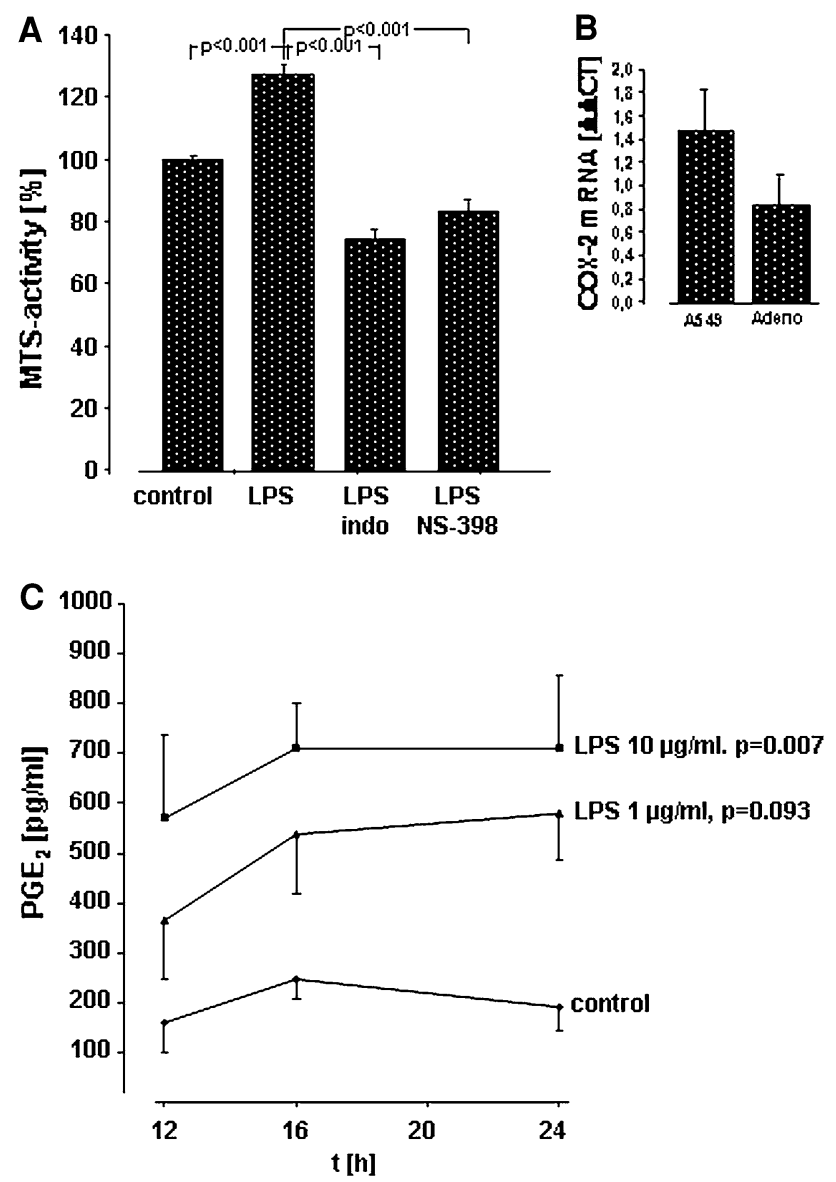

Fig. 3 Activation of COX-2 and release of $\mathrm{PGE}_{2}$ in A549 cells and human lung cancer tissue in response to LPS. a Effect of COX inhibitors on LPS-induced proliferation of A549 cells in vitro. A549 cells were either sham-incubated (control) or exposed to $10 \mu \mathrm{g} / \mathrm{ml}$ of LPS ( $n=3$ for LPS 0111:B4 and $n=3$ for LPS F515, total $n=6$ ) in the absence or presence of indomethacin (indo) or the COX-2 inhibitor NS-398. After $24 \mathrm{~h}$ of incubation proliferation was quantified by determining MTS activity. All data are expressed as percentage of unstimulated cells (control). Mean \pm SEM of six independent experiments are given. b Expression of COX-2 mRNA in response to LPS in A549 cells and human lung cancer tissue. A549 cells and specimen of human adenocarcinoma were either shamincubated or exposed to $10 \mu \mathrm{g} / \mathrm{ml}$ LPS F515. After $16 \mathrm{~h}$, mRNA was extracted and subjected to quantitative reverse transcriptase polymerase chain reaction. The $\Delta \Delta \mathrm{CT}$ values represent relative expression of COX-2 mRNA normalized to the internal reference HPRT mRNA in LPS versus unstimulated A549 cells or lung adenocarcinoma (Adeno) tissue. Mean values \pm SEM, originating from four independent experiments, each performed in duplicate are given. c Release of $\mathrm{PGE}_{2}$ in A549 cells in response to LPS. A549 cells were either shamincubated (control) or exposed to the given concentrations of LPS (at least $n=3$ for LPS 0111:B4 and $n=3$ for LPS F515, total at least $n=6$ ) for various time periods. $8 \mathrm{~h}$ before the end of the incubation period, and AA was added. $\mathrm{PGE}_{2}$ release into the cell supernatant is given in $\mathrm{pg} / \mathrm{ml}$. Data are expressed as mean \pm SEM of at least six independent experiments

\section{for HPRT}

5'GGTCCTTTTCACCAGCAAGCT3'8 (forward) and 5'TGACACTGGCAAAACAATGCA3' (reverse), for PCNA

5'TTTTCTGTCACCAAATTTGTACCTC3' (forward) and $5^{\prime}$ CTGCATTTAGAGTCAAGACCCTTT3' (reverse) for $\mathrm{Ki}-67$

$5^{\prime}$ AGAAGACAGTACCGCAGATGA3' (forward) and

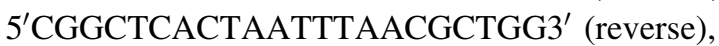
for COX-2

5'ATCATAAGCGAGGGCCAGCT3' (forward $101 \mathrm{bp}$ ) and 5'AAGGCGCAGTTTACGCTGTC3' (reverse $101 \mathrm{bp}$ ).

Real-time reactions were carried out on the Stratagene Mix Pro 3000 P (Agilent Technologies Inc) or the Sequence Detection System 7900 HT (Applied Biosystems) with following cycle conditions: denaturation, $95{ }^{\circ} \mathrm{C}$ for $10 \mathrm{~min}, 40$ cycles with denaturation at $95{ }^{\circ} \mathrm{C}$ for $30 \mathrm{~s}$, annealing at $58-60{ }^{\circ} \mathrm{C}$ for $30 \mathrm{~s}$ and extension at $72{ }^{\circ} \mathrm{C}$ for $30 \mathrm{~s}$. To ensure single-product amplification, a dissociation curve was generated for each gene and the threshold cycle ( $\mathrm{Ct}$ values) for each gene was determined. The comparative $2-\Delta \Delta \mathrm{Ct}$ method was used to analyze mRNA-fold changes between control and LPS, which was calculated as ratio $=2-(\Delta \mathrm{Ct}$ control- $\Delta \mathrm{Ct}$ LPS). $\mathrm{Ct}$ is the cycle threshold and $\Delta \mathrm{Ct}$ (Ct target $-\mathrm{Ct}$ reference) is the $\mathrm{CT}$ value normalized to the housekeeper gene HPRT obtained for the same cDNA samples [32, 33]. All samples were performed in triplicate, and all measurements were taken three times.

Histological examination of explanted tumors from the A549 adenocarcinoma mouse model

The tumors were frozen in liquid nitrogen and stored at $-80{ }^{\circ} \mathrm{C}$. For immunofluorescence, six LPS-treated tumors and eight unstimulated tumors were analyzed. $5 \mu \mathrm{m}$ whole tumor cross-sections were cut from the central part. Immunofluorescence staining has previously described in detail [34]. Briefly, whole tumor cross-sections were fixed with methanol and acetone (1:1) for $5 \mathrm{~min}$ and washed three times with PBS containing $0.1 \%$ BSA and $0.2 \%$ Triton X-100. The unspecific binding sites were blocked with $3 \%$ BSA in PBS for $1 \mathrm{~h}$. For Ki-67, slides were stained with a polyclonal rabbit anti-human nuclear Ki-67 (Abcam Ltd.332, ab833, Cambridge, UK, dilution 1:100 [35]. The secondary antibody, consisting of a goat antirabbit IgG (Alexa Fluor 488, Molecular Probes, Eugene, Oregon, USA) was applied at 1:1000. Each section was counterstained for $5 \mathrm{~min}$ with 40, 6-diamidino-2-phenylindole (DAPI, Sigma, Deisenhofen, Germany) and mounted with fluorescent mounting medium (Dako, Hamburg, Germany). The cyrosections were also stained with hematoxylin-eosin (H\&E) [36].

Microscopic analyses were performed using a fluorescence microscope (Leica DMLA Q550/W, Leica Microsystems, Bensheim, Germany) and Leica Q-Win standard 
software for quantification. The whole tumor cross-sections were sequentially scanned. After the scanning procedure, the Ki-67-positive signal of the whole tumor cross-section was detected, and this positive area was measured and related to the whole DAPI-positive area of the same tumor cross-section [37].

\section{Expression of Ki-67 in human lung cancer tissue}

Ki-67 was analyzed by immunohistochemistry (IHC) as described earlier [38]. Primary antibody MIB-1 (Dako, Glostrup, Denmark, $333 \mathrm{ng} / \mathrm{ml}$ ) was used in a final dilution of 1:100. After $30 \mathrm{~min}$ at room temperature, visualization was performed by horseradish-peroxidase labeled streptavidin-biotin technique (LSAB2 ${ }^{\mathrm{TM}}$, Dako, Denmark) diluted 1:3 and using 3-Amino9-Ethylcarbazole $/ \mathrm{H}_{2} \mathrm{O}_{2}$ as chromogen. Slides were counterstained with Mayer's hemalum and mounted with Kayser's glycerine gelatine. Negative controls were run by omitting the primary antibody.

\section{Statistics}

Unlike otherwise indicated, data are given as the relative changes compared to control values and expressed as the mean \pm SEM. Raw data were analyzed with R [39]. Linear mixed models were calculated using the package "lme" [40]. Raw data from time series were analyzed using the area-under-the-curve (AUC) approach. AUC values were calculated using the trapezoid rule. Percentages were analyzed using beta regression [41]. Linear mixed models were used for Figs. 1a, b, 2, 3a and 4. Linear models were used for Figs. 1c, d, 3c and 5a. Beta regression was used for Fig. 5b. Residuals of the models were checked for normal distribution, variance homogeneity and influential points. Reported $\mathrm{p}$ values are not corrected for multiple testing. Unless otherwise stated, p values below 0.05 keep a family-wise error rate of $5 \%$ (i.e., they would be $<0.05$ after Bonferroni correction).

\section{Results}

Induction of a time- and dose-dependent proliferation of A549 cells by LPS

The A549 monolayers were incubated with different concentrations of $\operatorname{LPS}(0.1,1$ and $10 \mu \mathrm{g} / \mathrm{ml})$ for various time periods $(8,24,48 \mathrm{~h})$. Two different endotoxins were used, either E. coli LPS 0111:B4 (Fig. 1a/c) or highly purified E.coli LPS F515 (Fig. 1b/d). Both LPS preparations stimulated the proliferation of A549 cells in a time- and dosedependent manner, as quantified by MTS assay and cell counting when compared to unstimulated controls. The maximal increase in metabolic activity was induced by $10 \mu \mathrm{g} / \mathrm{ml}$ endotoxin stimulation. In response to LPS from E. coli 0111:B4, MTS activity was increased to $129 \%$ after $24 \mathrm{~h}$ of stimulation and to $157 \%$ after $48 \mathrm{~h}$ of incubation (Fig. 1a). Similiar results were obtained for highly purified LPS from E. coli F515 (Fig. 1b), with an increase in MTS activity to $122 \%$ after $24 \mathrm{~h}$ and to $151 \%$ after
Fig. 4 Mechanisms of LPSinduced $\mathrm{PGE}_{2}$ synthesis. A549 cells were either shamincubated (control) or exposed to $10 \mu \mathrm{g} / \mathrm{ml}$ of LPS $(n=3$ for LPS 0111:B4 and $n=3$ for LPS F515, total $n=6$ ) in the absence or presence of neutralizing antibodies targeting TLR2, TLR4, CD14 and EGFR, or the COX inhibitor indomethacin (indo) and the specific COX-2 inhibitor NS398 for $24 \mathrm{~h} .8 \mathrm{~h}$ before the end of the incubation period, and $\mathrm{AA}$ was added. $\mathrm{PGE}_{2}$ release into the cell supernatant is given in $\mathrm{pg} / \mathrm{ml}$. Data are expressed as mean \pm SEM of at least six independent experiments

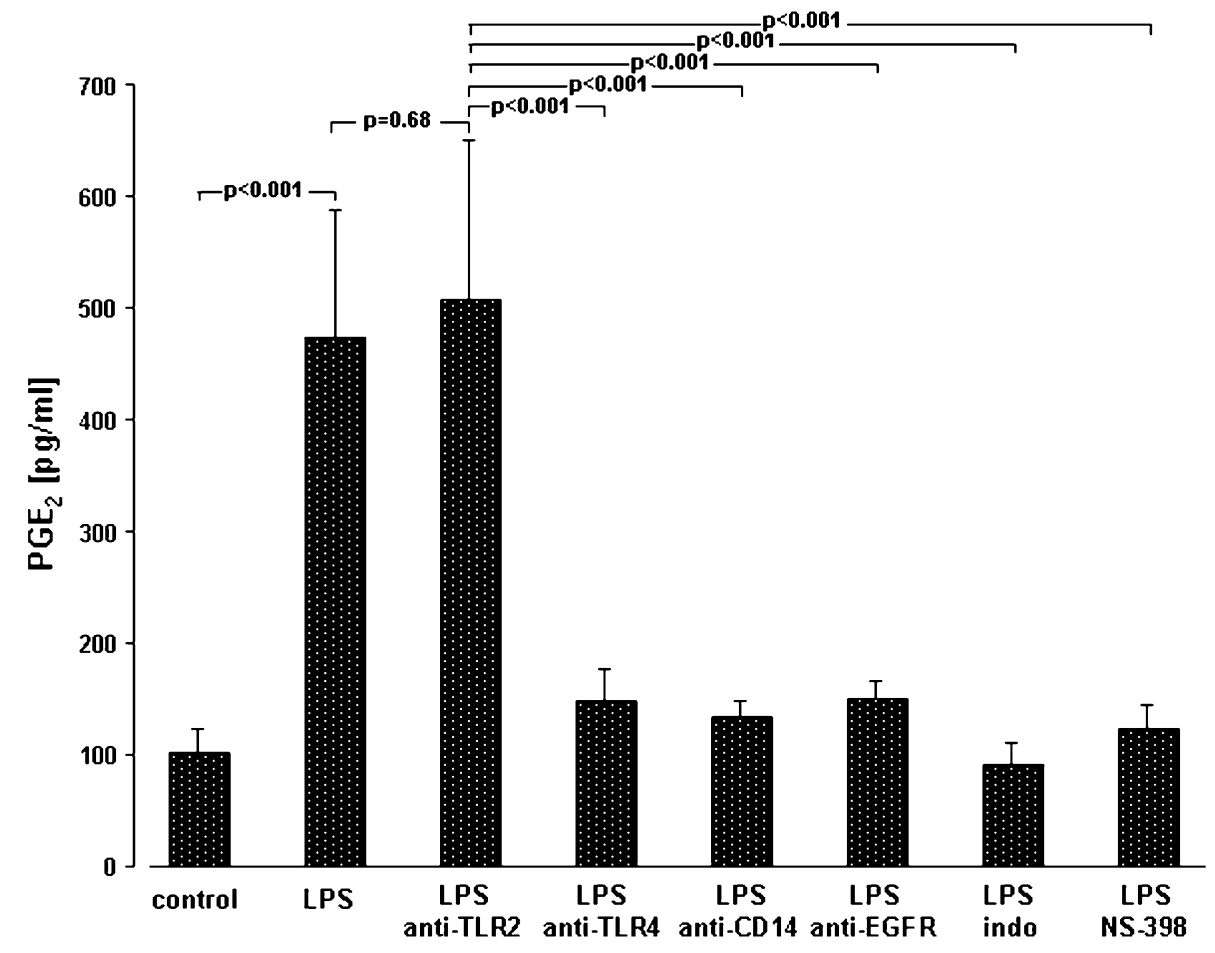



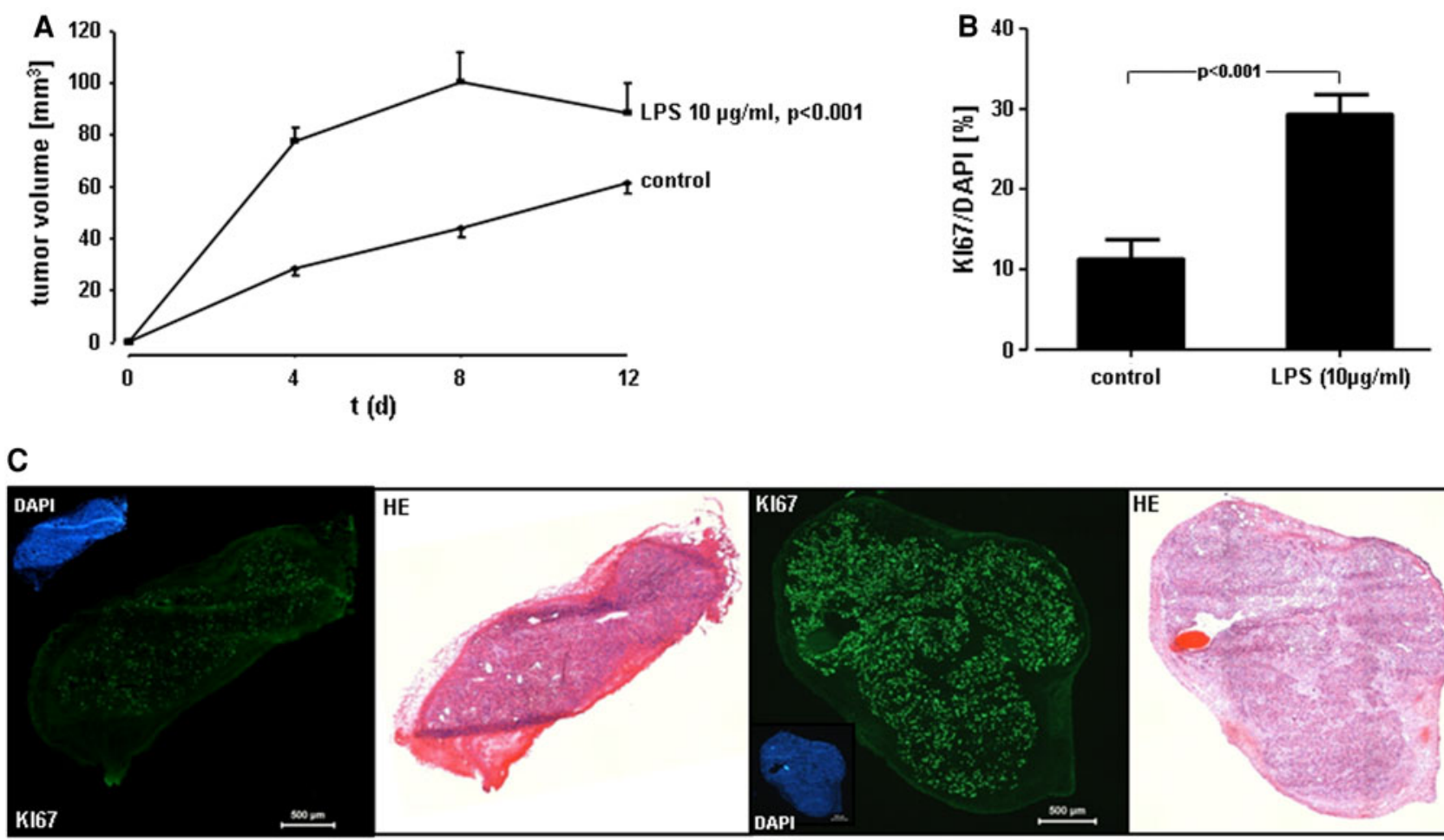

control

Fig. 5 Proliferative response of A549 cells in vivo. a In vivo tumor growth. A549 cells were exposed to $10 \mu \mathrm{g} / \mathrm{ml}$ of LPS F515, or sham incubation was performed. Immediately after treatment, cells were injected subcutaneously into 8-week-old female BALBc nu/nu mice. At indicated time points, the size of the tumor was measured by Mitutoyo digital calipers and is given in $\mathrm{mm}^{3}$. Data are expressed as mean \pm SEM ( $n=8$ for controls and $n=6$ for LPS). b Immunohistofluorescent analysis of Ki-67 in cryosections from A549 tumors.

$48 \mathrm{~h}$. Also, cell numbers were maximally increased upon exposure to $10 \mu \mathrm{g} / \mathrm{ml}$ endotoxin. After $24 \mathrm{~h}$, LPS from E. coli 0111:B4 elicited an increase in cell numbers to $191 \%$ and to $127 \%$ after $48 \mathrm{~h}$ (Fig. 1c), while stimulation with LPS from E.coli F515 was equally effective: cell counts were elevated to $201 \%$ after $24 \mathrm{~h}$ and to $138 \%$ after $48 \mathrm{~h}$, respectively. Continuous cellular growth was observed during the incubation period (untreated cells were counted as 745 cells after $8 \mathrm{~h}, 1,060$ cells after $24 \mathrm{~h}$ and 3,978 cells after $48 \mathrm{~h}$ ). Moreover, Ki-67 mRNA, as normalized to transcription of the internal standard gene HPRT was up-regulated $3.52 \pm 0.52$-fold, and PCNA mRNA was up-regulated $5.61 \pm 0.88$-fold in A549 cells after stimulation with $10 \mu \mathrm{g} / \mathrm{ml}$ LPS ( $n=6, n=3$ for LPS 0111:B4 and $n=3$ for LPS F515).

Mechanisms of LPS-induced A549 proliferation in vitro

In order to determine the molecular steps in A549 activation by endotoxin, studies with blocking antibodies

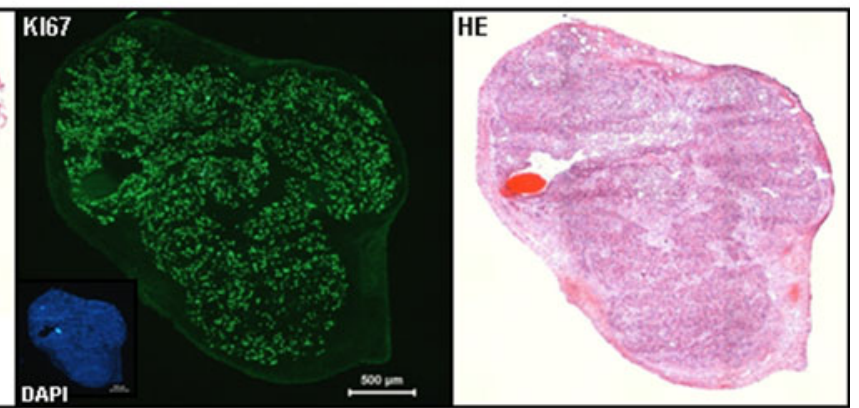

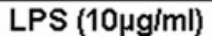

Quantitative analysis of $\mathrm{Ki}-67$ relative to DAPI (\%) from the experiments described in (a). Data reflect the mean \pm SEM $(n=8$ for controls and $n=6$ for LPS). c Immunofluorescent and H\&E staining. Representative images of untreated (control) versus LPSstimulated $(10 \mu \mathrm{g} / \mathrm{ml})$ A549 tumors and of the corresponding DAPI, Ki-67 and the H\&E staining, respectively. The scale bar corresponds to $500 \mu \mathrm{m}$

targeting CD14 (MY-4, $5 \mu \mathrm{g} / \mathrm{ml})$, TLR2 (TL2.1 $10 \mu \mathrm{g} / \mathrm{ml}$ ) or TLR4 (HTA125, $10 \mu \mathrm{g} / \mathrm{ml}$ ) were performed. As depicted in Fig. 2, LPS increased metabolic activity to $127 \%$ of unstimulated controls in the absence of blocking antibodies. However, this LPS-induced increase in metabolic activity was abolished in the presence of anti-CD14 $(102 \%)$ or anti-TLR4 (100\%), whereas blocking of TLR2 activity was not effective (128\%). In addition, targeting EGFR with cetuximab $(10 \mu \mathrm{g} / \mathrm{ml})$ suppressed the LPSinduced proliferation of A549 cells completely (96\%).

Activation of COX-2 and release of $\mathrm{PGE}_{2}$ in response to LPS

As COX-2-dependent prostanoids play a central role in NSCLC proliferation, the role of COX activation in response to LPS was investigated. In the presence of both the non-specific COX inhibitor indomethacin $(100 \mu \mathrm{M})$ and the COX-2-specific inhibitor NS-398 $(10 \mu \mathrm{M})$, the LPS-induced cellular proliferation $(127 \%)$ was reduced below control levels (reduction to $74 \%$ for indomethacin 
and to $83 \%$ for NS-398 compared with unstimulated controls, Fig. 3a).

In parallel, COX-2 mRNA in A549 cells and in ex vivo stimulated human NSCLC tissue specimens was up-regulated as reflected by the positive $\Delta \Delta \mathrm{CT}$ values for COX-2 mRNA in response to LPS (Fig. 3b). Moreover, a time- and dose-dependent accumulation of $\mathrm{PGE}_{2}$ was detected in the supernatant of LPS-stimulated A549 cells (Fig. 3c). Again, the higher $(10 \mu \mathrm{g} / \mathrm{ml})$ endotoxin concentration was most effective and elicited an almost fivefold increase in $\mathrm{PGE}_{2}$ after $24 \mathrm{~h}$. $\mathrm{TxB}_{2}$ was not released (data not shown). $\mathrm{PGE}_{2}$ synthesis in response to LPS could be effectively prevented by indomethacin $(100 \mu \mathrm{M})$ and the specific COX-2 inhibitor NS-398 $(10 \mu \mathrm{M})$. Both inhibitors diminished LPS-induced $\mathrm{PGE}_{2}$ release to control levels (Fig. 4). Corresponding to the LPS-activated proliferation of A549 cells, $\mathrm{PGE}_{2}$ release depended on ligation of TLR4 and CD14. Moreover, targeting EGFR also inhibited $\mathrm{PGE}_{2}$ release in response to LPS (Fig. 4).

Tumor cell proliferation in response to endotoxin in vivo

In order to investigate the effect of LPS on tumor growth in vivo, LPS-stimulated $(10 \mu \mathrm{g} / \mathrm{ml})$ or unstimulated A549 cells were injected subcutaneously into BALBc nu/nu mice. All mice developed tumors at the site of injection. The size of tumor xenografts was measured over a 12 days period. Already after 4 days, tumor growth was 2.8-fold enhanced upon LPS stimulation. In fact, tumor size was $27 \mathrm{~mm}^{3}$ in unstimulated tumors (control) and $78 \mathrm{~mm}^{3}$ in LPS-stimulated tumors (Fig. 5a). These growth effects of LPS were observed up to 12 days after tumor cell transplantation. The increase in tumor size was accompanied by a significant up-regulation of the proliferation marker $\mathrm{Ki}-67$, as assessed by immunofluorescence staining. In
LPS-stimulated tumors, $30 \%$ of cells expressed Ki-67 expression, while in unstimulated controls only $12 \%$ of tumor cells were Ki-67 positive (Fig. 5b).

Ki-67 expression in human lung cancer tissue after LPS exposure

Short-term stimulation of NSCLC tissue specimens using the ex vivo STST model [27] with $10 \mu \mathrm{g} / \mathrm{ml}$ LPS for $16 \mathrm{~h}$ revealed a twofold up-regulation of the proliferation marker Ki-67 as assessed by immunohistochemistry. Mean values of Ki-67 nuclear staining were $7.5 \pm 3.8 \%$ positive cells in untreated NSCLC specimens versus $15.0 \pm 5.77 \%$ positive cells in LPS-treated tissue specimens $(n=3)$.

Immunohistochemical staining of $\mathrm{Ki}-67$ in a representative human NSCLC specimen of adenocarcinoma type in the absence or presence of LPS is depicted in Fig. 6.

\section{Discussion}

Pulmonary infections are frequently encountered in lung cancer and may worsen prognosis in advanced stages of the disease. While therapy of lung cancer is often hampered by recurrent pulmonary infections, it is still unknown whether lung cancer growth and progression are actually accelerated by bacterial infections of the lung. In the present study, we demonstrated that purified endotoxin, the main pathogenicity factor of gram-negative bacteria, promotes tumor progression in A549 cells in vitro and in a mouse model assessing subcutaneous tumor growth of A549 cells transfected into nude mice. Importantly, the proliferationenhancing effect of LPS was also evident in ex vivo stimulated intact human tissue specimen obtained from patients with NSCLC, thus giving a strong hint on the clinical significance of the current data.

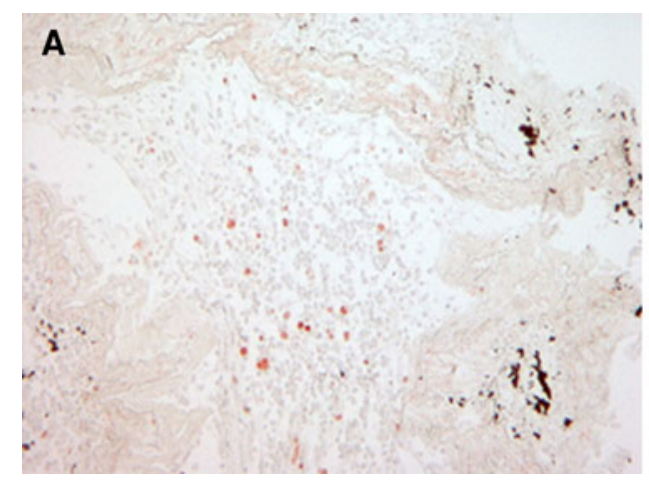

Fig. 6 Expression of Ki-67 in human non-small cell lung cancer tissue in response to LPS. Human lung adenocarcinomas were cultivated in the absence or presence of $10 \mu \mathrm{g} / \mathrm{ml}$ LPS F515 $(n=3)$ for $16 \mathrm{~h}$ and subsequently treated with the novel HOPE-fixation technique and paraffin-embedding method. After deparaffinization,

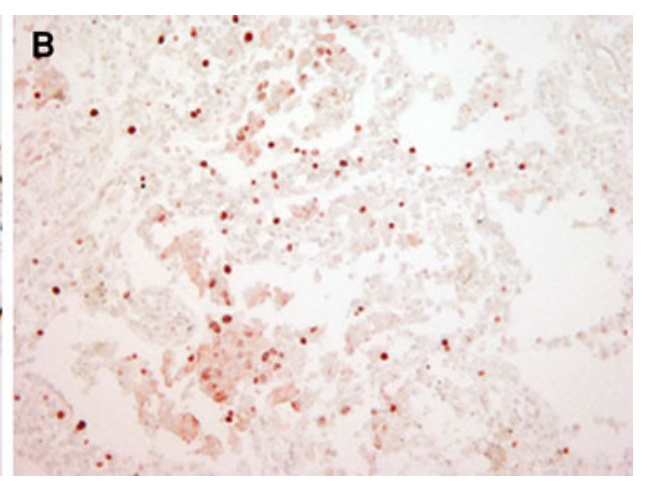

Ki-67 protein expression was assessed by IHC. One representative example of both an unstimulated (a) and LPS-stimulated (b) human NSCLC specimen of adenocarcinoma type is shown (magnification $\times 200$ ) 
Proliferation of tumor cells in response to LPS in A549 cells was induced by the ligation of LPS to CD14 and the pattern recognition receptor TLR4 followed by COX-2dependent $\mathrm{PGE}_{2}$ synthesis. Moreover, activation of EGFR was involved in LPS-activated tumor cell proliferation.

Our data suggest that LPS is a relevant and potent stimulator of tumor cell proliferation. In vitro, a clear doseand time-dependent increase in MTS activity was noted in A549 cells incubated with various concentrations of LPS. The increase in metabolic activity was already noted after $24 \mathrm{~h}$ of LPS treatment and reached a maximum after $48 \mathrm{~h}$. The metabolic activity of A549 cells is known to correspond to cellular proliferation [31], which was further validated by automatic cell counting with cell numbers being doubled after $24 \mathrm{~h}$ of LPS stimulation and further climbing thereafter, but to a lesser extent than MTS activity. As the best correlation between MTS activity and cell counts was evident after $24 \mathrm{~h}$ of stimulation, this time point was chosen for further experiments. In A549 cells, both the widely used LPS from E. coli 0111:B4 strain and a highly purified LPS preparation from E. coli strain F515 were equally effective, supporting the notion that this effect is not restricted to LPS of a certain bacterial strain or due to any contamination or preparation effect. Moreover, this proliferation- enhancing effect of LPS was not restricted to A549 cells. Intact human NSCLC tissue specimens that were stimulated ex vivo using the STST assay exhibited an increase in Ki-67 expression, a marker of cellular proliferation. The currently used HOPE-fixation technique for NSCLC specimen provides an excellent preservation of proteins and extremely low degradation of nucleic acids [29], thus allowing to illustrate most solidly the intact tumor's response to endotoxin. Additionally, in vivo tumor size was doubled in LPS-challenged tumors in the A549 adenocarcinoma mouse model. These results are in accordance with recent experimental data showing that LPS stimulates tumor growth in human ovarian cancer [42] and animal models of breast cancer [43] and induces apoptosis resistance of NSCLC cells [44].

The potential biologic significance of the proliferation enhancing effects of LPS are supported by the fact that the extent of LPS-induced cellular proliferation observed in our study approached or even exceeded that reported by well known other endo- or exogenous proliferative agents such as IL-8 [45] or benzo[a]pyrene [46]. It is noteworthy that even the single administration of low doses of LPS to A549 cells before subcutaneous implantation in the A549 adenocarcinoma mouse model was sufficient to induce a doubling of tumor size within the 12-day observation period.

As the currently described short-time tumor-promoting effects of endotoxin detected in vitro and in the subcutaneous tumor model might not reflect the physiological situation exactly, the effects of endotoxin and the potential mechanisms (i.e., TLR4, EGFR, COX-2 activation,) need to be validated in orthotopic lung cancer models, for example, in recently described in situ models using bioluminescence $[47,48]$.

However, our current experimental data clearly suggest that binding of LPS to the LPS receptors CD14 and TLR4 appears to be the initial steps in LPS-induced increase in proliferation. Application of both the blocking anti-CD14 antibody and the anti-TLR4 antibody suppressed the LPSinduced increase in MTS activity in A549-cells, whereas addition of the anti-TLR2 antibody was ineffective. This is of particular interest, as an up-regulation of TLR4 expression has been reported recently in human adenocarcinoma of the lung with TLR4 expression levels correlating with malignancy [26].

In our study, binding of LPS to CD14 and TLR4 was followed by the activation of COX-2 with subsequent $\mathrm{PGE}_{2}$ release. CD14/TLR4-dependent COX-2 activation may represent a crucial step in mediating tumor proliferation in response to endotoxin, and this conclusion is based on several reasons: first, when CD14 or TLR4 (but not TLR2) were blocked by the respective antibodies, no $\mathrm{PGE}_{2}$ was released from A549 cells and MTS activity as a marker of cell proliferation remained unchanged; second, when the non-specific COX inhibitor indomethacin was used, neither $\mathrm{PGE}_{2}$ release nor an increase in MTS activity was noted in LPS-stimulated A549 cells; third, the COX-2-specific inhibitor NS398 was equally effective in inhibiting prostanoid formation and MTS activity as compared to indomethacin; and fourth, marked expression of COX-2 mRNA in both A549 cells and in intact human ex vivo stimulated human lung cancer tissue was observed, following incubation with LPS. Therefore, $\mathrm{COX}-2$ is strongly suggested as the predominant isoform of $\mathrm{COX}$ engaged in mediating tumor cell proliferation. Whether COX-2-derived $\mathrm{PGE}_{2}$ is the key prostanoid mediating LPS-induced NSCLC proliferation cannot directly be derived from our data. However, $\mathrm{PGE}_{2}$ is the major prostanoid of A549 cells [16], is strongly induced in lung cancer tissue [15] and is known to promote NSCLC growth in vitro [11] and in vivo in a murine model of lung cancer [38].

In addition to CD14-and TLR4-dependent LPS-signaling, activation of the EGFR seems to be a crucial element of the observed tumor cell proliferation. When EGFR was blocked by cetuximab in A549 cells, both the LPS-induced increase in MTS activity and the release of $\mathrm{PGE}_{2}$ were blunted. This is of special interest, since overexpression of EGFR has been associated with tumor development and poor prognosis in NSCLC $[49,50]$ and novel inhibitors of this signaling pathway such as cetuximab, erlotinib and gefitinib are of increasing clinical importance [51-54]. 
Thus, EGFR inhibitors may equally be effective in inhibiting NSCLC growth triggered by infections.

The precise mechanism of LPS-induced EGFR activation cannot be derived from our data. Direct activation of this receptor system and downstream signaling events such as ERK and JNK activation in response to LPS have been described $[55,56]$. In addition, we and others have demonstrated that LPS activates IL-8 synthesis in A549 cells $[57,58]$, and this cytokine is known to transactivate EGFR in NSCLC cell lines as an alternative pathway [59].

In conclusion, this is the first study to demonstrate that LPS effectively induces tumor growth in various experimental models of NSCLC in vitro, ex vivo and in vivo via CD14-, TLR4-, EGFR- and COX-2-signaling. Our results support the hypothesis that pulmonary infections may severely worsen the prognosis of NSCLC by accelerating tumor progression.

Acknowledgments We would like to thank Martina Heep, Department of Internal Medicine IV/V, University of Giessen and Marburg Lung Center, Giessen, for expert technical assistance. We would like to thank Ursula Schombel, Immunochemistry Group, Research Center Borstel, Germany, for the purification of LPS from E. coli F515. This work was supported by the Deutsche Forschungsgemeinschaft (Excellence Cluster Cardiopulmonary System). Rajkumar Savai received additional support from the STARTUP AWARD's from the Justus-Liebig University Giessen.

Conflict of interest The authors declare that they have no conflict of interest.

Open Access This article is distributed under the terms of the Creative Commons Attribution License which permits any use, distribution, and reproduction in any medium, provided the original author(s) and the source are credited.

\section{References}

1. Pisani P, Parkin DM, Munoz N, Ferlay J (1997) Cancer and infection: estimated of the attributable fraction in 1990. Cancer Epidemiol Biomarkers Prev 6:387-400

2. Vogelmann R, Amieva MR (2007) The role of bacterial pathogens in cancer. Curr Opin Microbiol 10:76-81

3. Malfertheiner P, Sipponen P, Naumann M, Moayyedi P, Megraud F, Xiao SD, Sugano K, Nyren O (2005) Helicobacter pylori eradication has the potential to prevent gastric cancer: a state-ofthe-art critique. Am J Gastroenetrol 100:2100-2115

4. Crowe SE (2005) Helicobacter infection, chronic inflammation, and the development of malignancy. Curr Opin Gastroenterol 21:32-38

5. Putinati S, Trevisani L, Gualandi M, Guerra G, Rossi MR, Sartori S, Potena A (1994) Pulmonary infections in lung cancer patients at diagnosis. Lung Cancer 11:342-349

6. Berghmans T, Sculier JP, Klastersky J (2003) A prospective study of infections in lung cancer patients admitted to the hospital. Chest 124:114-120

7. Perlin E, Bang KM, Shah A, Hursey PD, Whittingham WL, Hashmi K, Campbell L, Kassim OD (1990) The impact of pulmonary infections on the survival of lung cancer patients. Cancer 66:593-596

8. Coussens LW, Werb Z (2002) Inflammation and cancer. Nature 420:860-867

9. Mantovani A, Allavena P, Sica A, Balkwill F (2008) Cancerrelated inflammation. Nature 454:436-444

10. Brown JR, DuBois RN (2004) Cyclooxygenase as a target in lung cancer. Clin Cancer Res 10:4266-4269

11. Zheng Y, Ritzenthaler JD, Sun X, Roman J, Han S (2009) Prostaglandin E2 stimulates human lung carcinoma cell growth through induction of integrin-linked kinase: the involvement of EP4 and Sp1. Cancer Res 69:896-904

12. Wolff H, Saukkonen K, Anttila S, Karjalainen A, Vainio H, Ristimäki A (1998) Expression of cyclooxygenase-2 in human lung carcinoma. Cancer Res 58:4997-5001

13. Achiwa H, Yatabe Y, Hida T, Kuroishi T, Kozaki K, Nakamura S, Ogawa M, Sugiura T, Mitsudomi T, Takahashi T (1999) Prognostic significance of elevated cyclooxygenase 2 expression in primary, resected lung adenocarcinomas. Clin Cancer Res 5:1001-1005

14. Lin MT, Lee RC, Yang PC, Ho FM, Kuo ML (2001) Cyclooxygenase-2 inducing Mcl-1-dependent survival mechanism in human lung adenocarcinoma CL1.0 cells. Involvement of phosphatidylinositol 3-kinase/Akt pathway. J Biol Chem 276: 48997-49002

15. McLemore TL, Hubbard WC, Litterst CL, Liu MC, Miller S, McMahon NA, Eggleston JC, Boyd MR (1988) Profiles of prostaglandin biosynthesis in normal lung and tumor tissue from lung cancer patients. Cancer Res 48:3140-3147

16. Hubbard WC, Alley MC, McLemore TL, Boyd MR (1988) Profiles of prostaglandin biosynthesis in sixteen established cell lines derived from human lung, colon, prostate, and ovarian tumors. Cancer Res 48:4770-4775

17. Pai R, Soreghan B, Szabo IL, Pavelka M, Baatar D, Tarnawski AS (2002) Prostaglandin E2 transactivates EGF receptor: a novel mechanism for promoting colon cancer growth and gastrointestinal hypertrophy. Nat Med 8:289-293

18. Ding J, Wu K, Zhang D, Luo W, Li J, Ouyang W, Song L, Huang C (2007) Activation of both nuclear factor of activated T cells and inhibitor of nuclear factor-kappa B kinase beta-subunit-/ nuclear factor-kappa B is critical for cyclooxygenase-2 induction by benzo[a]pyrene in human bronchial epithelial cells. Cancer Sci 98:1323-1329

19. Hwang D (2001) Modulation of the expression of cyclooxygenase- 2 by fatty acids mediated through toll-like receptor 4-derived signaling pathways. FASEB J 15:2556-2564

20. Wu S, Duan S, Zhao S, Cai Y, Chen P, Fang X (2005) Atorvastatin reduces lipopolysaccharide-induced expression of cyclooxygenase- 2 in human pulmonary epithelial cells. Respir Res 6:27

21. Wright SD, Ramos RA, Tobias PS, Ulevitch RJ, Mathison JC (1990) CD14, a receptor for complexes of lipopolysaccharide (LPS) and LPS binding protein. Science 249:1431-1433

22. Qureshi ST, Lariviere L, Leveque G, Clermont S, Moore KJ, Gros P, Malo D (1999) Endotoxin-tolerant mice have mutations in Toll-like receptor 4. J Exp Med 189:615-619

23. Takeda K, Akira S (2005) Toll-like receptors in innate immunity. Int Immunol 17:1-14

24. Netea MG, van Deuren M, Kullberg BJ, Cavaillon JM, Van der Meer JW (2002) Does the shape of lipid A determine the interaction of LPS with Toll-like receptors? Trends Immunol 23:135-139

25. Schmausser B, Andrulis M, Endrich S, Müller-Hermelink HK, Eck M (2005) Toll-like receptors TLR4, TLR5 and TLR9 on gastric carcinoma cells: an implication for interaction with Helicobacter pylori. Int J Med Microbiol 295:179-185 
26. Zhang YB, He FL, Fang M, Hua TF, Hu BD, Zhang ZH, Cao Q, Liu RY (2009) Increased expression of Toll-like receptors 4 and 9 in human lung cancer. Mol Biol Rep 36:1475-1481

27. Lang DS, Droemann D, Schultz H, Branscheid D, Martin C, Ressmeyer AR, Zabel P, Vollmer E, Goldmann T (2007) A novel human ex vivo model for the analysis of molecular events during lung cancer chemotherapy. Respir Res 14:43

28. Wiese A, Brandenburg K, Lindner B, Schromm AB, Carroll SF, Rietschel ET, Seydel U (1997) Mechanisms of action of the bactericidal/permeability-increasing protein BPI on endotoxin and phospholipid monolayers and aggregates. Biochemistry 36:10301-10310

29. Olert J, Wiedorn KH, Goldmann T, Kühl H, Mehraein Y, Scherthan H, Neketeghad F, Vollmer E, Muller AM, MullerNavia J (2001) HOPE-fixation: a novel fixing method and paraffin-embedding technique for human soft tissues. Pathol Res Pract 197:823-826

30. Savai R, Schermuly RT, Voswinckel R, Renigunta A, Reichmann B, Eul B, Grimminger F, Seeger W, Rose F, Hänze J (2005) HIF1alpha attenuates tumor growth in spite of augmented vascularization in an A549 adenocarcinoma mouse model. Int J Oncol 27:393-400

31. Cory AH, Owen TC, Barltrop JA, Cory JG (1991) Use of an aqueous soluble tetrazolium/formazan assay for cell growth assays in culture. Cancer Commun 3:207-212

32. Fink L, Seeger W, Ermert L, Hänze J, Stahl U, Grimminger F, Kummer W, Bohle RM (1998) Real-time quantitative RT-PCR after laser-assisted cell picking. Nat Med 4:1329-1333

33. Kolosionek E, Savai R, Ghofrani HA, Weissmann N, Guenther A, Grimminger F, Seeger W, Banat GA, Schermuly RT, Pullamsetti SS (2009) Expression and activity of phosphodiesterase isoforms during epithelial mesenchymal transition: the role of phosphodiesterase 4. Mol Biol Cell 20:4751-4765

34. Kamlah F, Eul B, Li S, Lang N, Marsh LM, Seeger W, Grimminger F, Rose F, Hänze J (2009) Intravenous injection of siRNA directed against hypoxia-inducible factors prolongs survival in a Lewis lung carcinoma cancer model. Cancer Gene Ther 16:195-205

35. Floyd HS, Farnsworth CL, Kock ND, Mizesko MC, Little LJ, Dance ST, Everitt J, Tichelaar J, Whitsett JA, Miller MS (2005) Conditional expression of the mutant Ki-rasG12C allele results in formation of benign lung adenomas: development of a novel mouse lung tumor model. Carcinogenesis 26: 2196-2206

36. Kamlah F, Hänze J, Arenz A, Seay U, Hasan D, Juricko J, Bischoff B, Gottschald OR, Fournier C, Taucher-Scholz G, Scholz M, Seeger W, Engenhart-Cabillic R, Rose F (2011) Comparison of the effects of carbon ion and photon irradiation on the angiogenic response in human lung adenocarcinoma cells. Int J Radiat Oncol Biol Phys 80:1541-1549

37. Fokas E, Hänze J, Kamlah F, Eul BG, Lang N, Keil B, Heverhagen JT, Engenhart-Cabillic R, An H, Rose F (2010) Irradiationdependent effects on tumor perfusion and endogenous and exogenous hypoxia markers in an A549 xenograft model. Int $\mathbf{J}$ Radiat Oncol Biol Phys 77:1500-1508

38. Goldmann T, Vollmer E, Gerdes J (2003) What's cooking? Detection of important biomarkers in HOPE-fixed paraffin embedded tissues eliminates the need for antigen retrieval. Am J Pathol 163:2638-2640

39. R Development Core Team (2011) R: a language and environment for statistical computing. R Foundation for Statistical Computing, Vienna, Austria. ISBN 3-900051-07-0, URL http:// www.R-project.org/

40. Bates D, Maechler M, Bolker B (2011) lme4: Linear mixedeffects models using S4 classes. R package version 0.999375-42. http://CRAN.R-project.org/package=lme 4
41. Cribari-Neto F, Zeileis A (2010) Beta regression in R. J Stat Softw 34(2) 1-24. URL http://www.jstatsoft.org/v34/i02/

42. Kelly MG, Alvero AB, Chen R, Silasi DA, Abrahams VM, Chan S, Visintin I, Rutherford T, Mor G (2006) TLR-4 signaling promotes tumor growth and paclitaxel chemoresistance in ovarian cancer. Cancer Res 66:3859-3868

43. Harmey JH, Bucana CD, Lu W, Byrne AM, McDonnell S, Lynch C, Bouchier-Hayes D, Dong Z (2002) Lipopolysaccharideinduced metastatic growth is associated with increased angiogenesis, vascular permeability and tumor cell invasion. Int $\mathrm{J}$ Cancer 101:415-422

44. He W, Liu Q, Wang L, Chen W, Li N, Cao X (2007) TLR4 signaling promotes immune escape of human lung cancer cells by inducing immunosuppressive cytokines and apoptosis resistance. Mol Immunol 11:2850-2859

45. Zhu YM, Webster SJ, Flower D, Woll PJ (2004) Interleukin-8/ CXCL8 is a growth factor for human lung cancer cells. Br J Cancer 91:1970-1976

46. Kometani T, Yoshino I, Miura N, Okazaki H, Ohba T, Takenaka T, Shoji F, Yano T, Maehara Y (2009) Benzo[a]pyrene promotes proliferation of human lung cancer cells by accelerating the epidermal growth factor receptor signaling pathway. Cancer Lett 278:27-33

47. Li B, Torossian A, Li W, Schleicher S, Niu K, Giacalone NJ, Kim SJ, Chen H, Gonzalez A, Moretti L, Lu B (2011) A novel bioluminescence orthotopic mouse model for advanced lung cancer. Radiat Res 176:486-493

48. Saha D, Watkins L, Yin Y, Thorpe P, Story MD, Song K, Raghavan P, Timmerman R, Chen B, Minna JD, Solberg TD (2010) An orthotopic lung tumor model for image-guided microirradiation in rats. Radiat Res 174(1):62-71

49. Kurie JM, Shin HJ, Lee JS, Morice RC, Ro JY, Lippman SM, Hittelman WN, Yu R, Lee JJ, Hong WK (1996) Increased epidermal growth factor receptor expression in metaplastic bronchial epithelium. Clin Cancer Res 2:1787-1793

50. Hirsch FR, Varella-Garcia M, Bunn PA Jr, Di Maria MV, Veve R, Bremmes RM, Barón AE, Zeng C, Franklin WA (2003) Epidermal growth factor receptor in non-small-cell lung carcinomas: correlation between gene copy number and protein expression and impact on prognosis. J Clin Oncol 21:3798-3807

51. Shepherd FA, Rodrigues Pereira J, Ciuleanu T, Tan EH, Hirsh V, Thongprasert S, Campos D, Maoleekoonpiroj S, Smylie M, Martins R, van Kooten M, Dediu M, Findlay B, Tu D, Johnston D, Bezjak A, Clark G, Santabárbara P, Seymour L, National Cancer Institute of Canada Clinical Trials Group (2005) Erlotinib in previously treated non-small-cell lung cancer. N Engl J Med 14:123-132

52. Mok TS, Wu YL, Thongprasert S, Yang CH, Chu DT, Saijo N, Sunpaweravong P, Han B, Margono B, Ichinose Y, Nishiwaki Y, Ohe Y, Yang JJ, Chewaskulyong B, Jiang H, Duffield EL, Watkins CL, Armour AA, Fukuoka M (2009) Gefitinib or carboplatin-paclitaxel in pulmonary adenocarcinoma. N Engl J Med 361:947-957

53. Pirker R, Pereira JR, Szczesna A, von Pawel J, Krzakowski M, Ramlau R, Vynnychenko I, Park K, Yu CT, Ganul V, Roh JK, Bajetta E, O'Byrne K, de Marinis F, Eberhardt W, Goddemeier T, Emig M, Gatzemeier U, FLEX Study Team (2009) Cetuximab plus chemotherapy in patients with advanced non-small-cell lung cancer (FLEX): an open-label randomised phase III trial. Lancet 373:1525-1531

54. Janku F, Stewart DJ, Kurzrock R (2010) Targeted therapy in nonsmall-cell lung cancer-is it becoming a reality? Nat Rev Clin Oncol 7:401-414

55. Lin WN, Luo SF, Wu CB, Lin CC, Yang CM (2008) Lipopolysaccharide induces VCAM-1 expression and neutrophil adhesion to human tracheal smooth muscle cells: involvement of $\mathrm{Src} /$ 
EGFR/PI3-K/Akt pathway. Toxicol Appl Pharmacol 228: 256-268

56. Tabassam FH, Graham DY, Yamaoka Y (2009) Helicobacter pylori activate epidermal growth factor receptor- and phosphatidylinositol 3-OH kinase-dependent Akt and glycogen synthase kinase 3beta phosphorylation. Cell Microbiol 11:70-82

57. Grandel U, Heygster D, Sibelius U, Fink L, Sigel S, Seeger W, Grimminger F, Hattar K (2009) Amplification of lipopolysaccharide-induced cytokine synthesis in non-small cell lung cancer/neutrophil cocultures. Mol Cancer Res 7:1729-1735
58. Liu J, Abate W, Xu J, Corry D, Kaul B, Jackson SK (2011) Three-dimensional spheroid cultures of A549 and HepG2 cells exhibit different lipopolysaccharide (LPS) receptor expression and LPS-induced cytokine response compared with monolayer cultures. Innate Immun 17:245-255

59. Luppi F, Longo AM, de Boer WI, Rabe KF, Hiemstra PS (2007) Interleukin-8 stimulates cell proliferation in non-small cell lung cancer through epidermal growth factor receptor transactivation. Lung Cancer 56:25-33 